\title{
The Relationship Between Knowledge and Clean Behavior and Healthy Lifestyle on the Incidence of Scabies at Boarding School Students
}

\author{
Lina Damayanti* \\ Department of Dermatovenerology, Medical Faculty \\ Universitas Jenderal Achmad Yani \\ Cimahi, Indonesia \\ *lina.damayanti@fk.unjani.ac.id \\ Alex Siagian \\ Department of Anesthesiology, Medical Faculty \\ Universitas Jenderal Achmad Yani \\ Cimahi, Indonesia
}

\author{
Meiliza Zailani \\ Medical Faculty \\ Universitas Jenderal Achmad Yani \\ Cimahi, Indonesia
}

Aditya Yudha Pratama

Medical Faculty

Universitas Jenderal Achmad Yani

Cimahi, Indonesia

\begin{abstract}
Scabies is a contagious skin infection caused by infestation and sensitization of female mites Sarcoptes scabiei varieta hominis and its products. Scabies is also known as The Itch, Sky-Bees, Scabies, and Itchy Agogo. The prevalence of scabies in developing countries, including Indonesia is $4.6 \%$ $12.95 \%$ and the third of the 12 most common skin diseases that occur in the community. The most dominant factor is knowledge and behavior factors. The purpose of this study was to analyze the relationship between the level of knowledge and the clean behavior and healthy lifestyle on the incidence of scabies in students. The research method was observational analytic with cross sectional observation. A sample of 34 people was taken by simple random technique. Data is taken through physical examination and using a questionnaire. Data were analyzed using the Chi Square Test statistic test. The results showed that there was a significant relationship between the level of knowledge with the incidence of scabies $(p=0,007)$ and there was a significant relationship between the level of clean and healthy living behavior with the incidence of scabies $(p=0,015)$. The results of research, a very important factor related to scabies is lack of knowledge and poor personal hygiene problems.
\end{abstract}

Keywords—knowledge, clean and healthy behavior, scabies

\section{INTRODUCTION}

Scabies in Indonesia is more commonly known as kudis, gudig, and budug. Scabies is a contagious skin infection caused by the infestation and sensitization of the female mite Sarcoptes scabiei varieta hominis and its products. Tropical countries are endemic countries of scabies [1-4].

According to WHO, scabies is spread throughout the world, affecting about 300 million cases per year with a prevalence that varies and changes. This disease can affect all individuals regardless of gender, age, and race and tends to be more common in children and adolescents [5,6]. The prevalence of scabies in the world, such as India, is $20.4 \%$, Nigeria $28.6 \%$, Australia 30\%, and Malaysia 31\%. According to the Indonesian Ministry of Health, the prevalence of scabies in Indonesia is $4.6 \%-12.95 \%$ and is the third of the 12 most common skin diseases that occur in communities with the highest incidence rate in West Java and the lowest in North Sumatra [6].

In the community, scabies is a neglected disease that is considered normal and commonplace because it is not life threatening, even though scabies is an infectious disease so the priority for handling it is low which sometimes can cause scabies to become chronic and severe. Scabies causes intense itching that will disturb sleep so that the next day the sufferer is drowsy, dizzy, and other complaints due to lack of sleep. Scabies lesions also reduce self-confidence in most sufferers. Female patients usually feel embarrassed with this condition and $30 \%$ withdrew from social activities because they are not confident. The result of scratching due to itching will cause erosion, excoriation, crusting, eczema, and secondary infection $[5,6]$.

Factors that contribute to the high prevalence of scabies are inadequate socioeconomic conditions, poor personal hygiene and behavior, high occupancy density (prisons, barracks, flats, and Islamic boarding schools), environmental factors, misdiagnosis, inappropriate management, and lack of knowledge on the prevention of scabies. The diagnosis of scabies is characterized by the occurrence of itching at night where mite activity is higher at hotter and more humid temperatures, attacks a group of people who live together, 
finding tunnels (canaliculi) in the predilection site, and finding mites and their eggs and feces $[7,8]$.

Islamic boarding schools are one of the most densely populated places that are occupied by a group of people at the same time. The fact is that some Islamic boarding schools have grown up in slum environments, dirty baths and toilets, insufficient availability of clean water, humid environments, and poor sanitation. Usually in Islamic boarding schools there will be frequent physical interactions and contacts between individuals. Bad habits often occur in Islamic boarding schools, such as the habit of borrowing personal items from each other, rarely drying the mattress, rarely changing pillowcases and bed sheets. These will lead to ease the transmission of scabies [9$11]$.

According to the Indonesian Ministry of Health, a clean and healthy lifestyle is an effort to familiarize people with healthy and clean behavior to identify problems and their health. Have a clean and healthy lifestyle, for example washing hands with soap, managing drinking water and food that meets the requirements, using clean water, and using clean toilets $[12,13]$. Personal hygiene is a factor that is closely related to one indicator of a clean and healthy lifestyle. Personal hygiene will consciously determine health status in maintaining health and preventing various diseases, especially skin diseases [14].

The incidence of scabies in Islamic boarding schools from 2013-2016 ranged from 24.6\%-54.7\% [15]. Several studies have shown that scabies still shows various results. Research at Al-Ikhwan Islamic Boarding School Pekanbaru in 2017 from 83 respondents showed the incidence of scabies was $69.9 \%$ with poor personal hygiene which amount of $49.4 \%$ [16,17]. Ciamis is one of the districts in West Java Province where there are many Islamic boarding schools, there are 424 Islamic boarding schools and Cidolog is one of the sub-districts in Ciamis which has 2 Islamic boarding schools, one of them is the Al Baaqiyaatushsholihaat Islamic Boarding School. According to data from Cidolog public health center, there were 316 cases of scabies in 2018 but most of the students experienced it at the $\mathrm{Al}$ Baaqiyaatushsholihaat Islamic Boarding School [18].

From the results of the researcher's initial survey, the surrounding environment at the $\mathrm{Al}$ Baaqiyaatushsholihaat Islamic Boarding School was poorly maintained and the habits of students in the Islamic boarding school who rarely cleaned the bedroom and often used other students' personal items simultaneously, the habit of sleeping together, the habit of hanging clothes together, and the habit of washing clothes with their friends.

Based on these reasons and the research has never been carried out at the Al Baaqiyaatushsholihaat Islamic Boarding School, the researchers are interested in conducting research on the relationship between the level of knowledge and clean and healthy living behavior on scabies in students at the Islamic boarding school, Cidolog District, Ciamis Regency.

\section{METHODS}

This research was conducted using an observational method with a cross sectional approach. The data taken is based on primary data, which consist of direct physical examination and distribution of questionnaires. The population in this study were all students living in Al Baaqiyaatushsholihaat Islamic Boarding School who met the inclusion criteria (all students who lived and stayed in Al Baaqiyaatushsholihaat Islamic Boarding School and were willing to become respondents by signing the informed consent) and exclusion criteria (students who were not present at the time of the study period). Data were collected using a total sampling method. Data were analysed using univariable and bivariable analysis. The statistical test used in this study is the Chi Square Test statistical test.

\section{RESULTS AND DISCUSSION}

This research was conducted at the $\mathrm{Al}$ Baaqiyaatushsholihaat Islamic Boarding School, Cidolog District, Ciamis Regency between December-January 2019. The results of the study were taken from physical examination data on respondents and from the results of filling out questionnaires. The number of samples that met the inclusion criteria and exclusion criteria was 34 people. The sample characteristics observed included gender, age, incidence of scabies among respondents, clean behavior and healthy lifestyle of respondents, and knowledge of scabies among respondents.

\section{A. Characteristics of Respondents Based on Gender}

Table 1 shows that the respondents at $\mathrm{Al}$ Baaqiyaatushsholihaat Islamic Boarding School who experienced scabies were 29 people $(85.3 \%)$ with occurred in 15 female respondents $(44.12 \%)$ and 14 male respondents $(41,18 \%)$. The number of respondents who did not experience scabies were 5 people which consist of 3 females $(8,82 \%)$ and 2 males $(5.88 \%)$.

TABLE I. CHARACTERISTICS OF RESPONDENTS BASED ON GENDER

\begin{tabular}{|l|l|l|l|l|l|l|}
\hline \multirow{3}{*}{ Variable } & \multicolumn{9}{c}{ Scabies } \\
\cline { 2 - 7 } & \multicolumn{2}{|c|}{ Positive } & \multicolumn{2}{c|}{ Negative } & \multicolumn{2}{c|}{ Total } \\
\cline { 2 - 7 } & Amount & \% & Amount & \% & Amount & \% \\
\hline Gender & 14 & 41,18 & 2 & 5,88 & 16 & 47,1 \\
\hline Male & 14 & 44,12 & 3 & 8,82 & 18 & 52,9 \\
\hline Female & 15 & \multicolumn{5}{|c|}{}
\end{tabular}

The results of a study conducted by Naftassa et al. stated that the prevalence of scabies was $82.0 \%$ [19]. The results of another study conducted by Handari et al. stated that the prevalence of scabies was $65.3 \%$ [20]. The high prevalence of scabies in Al Baaqiyaatushsholihaat Islamic Boarding School can be caused by several factors, including a lack of knowledge and a lack of awareness of clean and healthy living habits.

This study is also in line with the research conducted by Ibadurrahmi et al., where the study showed that females were 
more likely to suffer from scabies with a percentage of $53.6 \%$ [9]. In the literature, it is stated that there is no difference in the incidence rate between the sexes of men and women. Both have the same chance of experiencing scabies [2].

\section{B. Characteristics of Respondents Based on Ages}

In Table 2 shows that the average age at $\mathrm{Al}$ Baaqiyaatushsholihaat Islamic Boarding School is 15,68 years with a standard deviation of the young age of the respondents is 14 years old and the oldest is 19 years old.

TABLE II. ChaRACTERISTICS OF RESPONDENTS BASED ON AgES

\begin{tabular}{|c|l|l|l|}
\hline Variable & \multicolumn{3}{|c|}{ Scabies } \\
\hline \multirow{2}{*}{ Ages } & Positive & Negative & Total \\
\cline { 2 - 4 } & $15,59(1,72)$ & $16,20(1,64)$ & $15,68(1,70)$ \\
\hline
\end{tabular}

The average age of this study was 15,59 . This study is in line with research conducted by Avidah et al. which states that the risk of getting scabies increase at age 11-16 years compared with age above 17 years. This may occur due to the increased level of health awareness over 17 years of age so that in this age group efforts to prevent the transmission of scabies can be carried out [21].

This research is also in line with one of the literatures which states that in several developing countries, the prevalence of scabies tends to be high in children and adolescents [2].

\section{Characteristics of Respondents Based on Knowledge about Scabies}

The above results indicate that scabies is one of the main health problems that need attention. Although scabies is not life-threatening, it deserves attention because of its high transmission rate and can interfere with the quality of life of the affected person [2].

In Table 3 shows that knowledge of respondents about scabies is hinger in "poor" category with the number 26 respondents $(76,5 \%)$ when compared to "adequate" category of 8 respondents $(23.5 \%)$.

TABLE III. CHARACTERISTICS OF RESPONDENTS BASED ON KNOWLEDGE ABOUT SCABIES

\begin{tabular}{|l|l|l|}
\hline \multicolumn{1}{|c|}{ Variable } & Amount & Percentage (\%) \\
\hline Knowledge & 26 & 76,5 \\
\hline Poor & 8 & 23,5 \\
\hline Adequate & 34 & 100,0 \\
\hline Total & \multicolumn{2}{|c|}{} \\
\hline
\end{tabular}

Low knowledge in this study was similar to the results of research conducted by Ridwan et al. mention that the percentage of research knowledge of scabies among respondents is still low at $57,7 \%$ [22]. Another study conducted by Ma'rufi et al. stated that the percentage of knowledge about scabies was still low among respondents, namely $70.5 \%$ [5].
This can be caused by the majority of respondents in this study who were 15 years old and still in junior high school so that the knowledge that is known is not much. Some respondents did not know the cause of scabies, how it is transmitted, and how it is treated. According to Notoatmojo, the higher the level of education of a person, it can increase the person's knowledge, including knowledge about health and can reduce the risk of developing diseases including scabies [23].

\section{Characteristics of Respondents Based on Clean Behavior and Healthy Lifestyle}

Table 4 shows that the behavior of clean and healthy life among respondents is more in the "poor" category with a total of 29 respondents $(85,3 \%)$ when compared to those in the "adequate" category amounted 5 respondents (14.7\%).

\section{TABLE IV. CHARACTERISTICS OF RESPONDENTS BASED ON CLEAN BEHAVIOR AND HEALTHY LIFESTYLE}

\begin{tabular}{|l|l|l|}
\hline \multicolumn{1}{|c|}{ Variable } & \multicolumn{1}{c|}{ Amount } & Percentage (\%) \\
\hline Clean Behavior an Healthy Lifestyle \\
\hline Poor & 29 & 85,3 \\
\hline Adequate & 5 & 14,7 \\
\hline Total & 34 & 100,0 \\
\end{tabular}

The results above are in line with previous studies. Research conducted by Ma'rufi et al. stated that the clean and healthy life behavior carried out by respondents was still low with a percentage of $70 \%$ [5]. This can be caused by the low level of knowledge and attitudes of respondents regarding health. Unhealthy behavior when in contact with people with scabies or objects that have been contaminated with scabies mites will be more at risk of contracting scabies, because mites are easier to infest individuals with unhealthy behavior. The opposite applies if the respondent has a clean and healthy lifestyle when in contact with the source of the scabies infection it will be more difficult to be infected by the mites that cause scabies because it can be prevented by bathing using soap, changing clothes every day, washing clothes with soap, ironing clothes, and living clean and other healthy habits [2]

\section{E. Relationship between Knowledge and Incidence of Scabies}

Table 5 shows that there were 4 respondents with good knowledge who had scabies $(50 \%)$ and 4 people who did not experience scabies $(50 \%)$. Meanwhile, respondents who had less knowledge who experienced scabies were 25 people $(92,6 \%)$ and those who did not experience scabies for the low knowledge category were 1 person $(3.8 \%)$.

TABLE V. RELATIONSHIP BETWEEN KNOWLEDGE AND INCIDENCE OF SCABIES

\begin{tabular}{|c|c|c|c|c|c|c|c|}
\hline \multirow{3}{*}{ Variable } & \multicolumn{6}{|c|}{ Scabies } & \multirow{3}{*}{$\begin{array}{c}\text { p- } \\
\text { value }\end{array}$} \\
\hline & \multicolumn{2}{|c|}{ Positive } & \multicolumn{2}{|c|}{ Negative } & \multicolumn{2}{|c|}{ Total } & \\
\hline & Amount & $\%$ & Amount & $\%$ & Amount & $\%$ & \\
\hline \multicolumn{7}{|c|}{ Knowledge } & \multirow{3}{*}{0,007} \\
\hline Adequ & 4 & 50,0 & 4 & 50,0 & 8 & 100,0 & \\
\hline Poor & 25 & 92,6 & 1 & 3,8 & 26 & 100,0 & \\
\hline
\end{tabular}


Based on the table above, the results of statistical tests using the chi square test analysis at the 95\% degree of confidence showed that there was a statistically significant relationship between knowledge and the incidence of scabies in respondents with a value of $p=0.007$ ( $p$ value $\leq 0.05$ )

This study is in line with the research of Ibadurrahmmi et al., which states that out of 285 respondents, $60.6 \%$ of respondents who have poor knowledge about scabies suffer more from scabies and state that there is a relationship between knowledge and the incidence of scabies [9]. Another study conducted by Rohmawati also showed that out of 155 respondents, around $81.58 \%$ of respondents had poor knowledge about scabies and had more scabies [24]. This is also supported by research conducted by Hilma and Ghazali which states that the higher prevalence of scabies occurs in respondents with poor knowledge, namely 46 respondents who have poor knowledge about scabies, 28 respondents $(60.9 \%)$ suffer from scabies [25].

The results of this study are in accordance with that stated by Notoatmodjo who stated that knowledge can be known if someone has been in contact with the object, where most of the knowledge can be obtained from seeing and hearing. Knowledge is the initial introduction to an object being observed, so that if the knowledge is not good about an object it will affect the behavior that will be carried out. There are still many respondents who do not know about the way scabies is transmitted, which has an impact on the continuity of the disease among respondents [23]. The lack of knowledge of students at the Al Baaqiyaatushsholihaat Islamic Boarding School regarding scabies is due to a lack of health education regarding personal hygiene and skin diseases, especially scabies from the local health center so that the Islamic boarding school's management and students pay less attention to environmental cleanliness around the school and personal hygiene because they don't know the impact of lack of cleanliness from the surrounding environment and themselves.

\section{F. Relationship between Clean Behavior and Healthy Lifestyle and Incidence of Scabies}

Table 6 shows that respondents with a good level of clean and healthy living who experienced scabies were 2 respondents $(40,0 \%)$ and those who did not experience scabies were 3 respondents $(60.0 \%)$. While respondents to the level of hygienic behavior and less healthy, who have scabies as many as 27 respondents $(93,1 \%)$ and who had not had scabies for good category as many as $2(6.9 \%)$.

TABLE VI. RELATIONSHIP BETWEEN CLEAN BEHAVIOR AND HEALTHY LIFESTYLE AND INCIDENCE OF SCABIES

\begin{tabular}{|l|l|l|l|l|l|l|c|}
\hline \multirow{3}{*}{ Variable } & \multicolumn{5}{|c|}{ Scabies } & \multirow{2}{*}{$\begin{array}{c}\text { p- } \\
\text { value }\end{array}$} \\
\cline { 2 - 6 } & \multicolumn{2}{|c|}{ Positive } & \multicolumn{2}{c|}{ Negative } & \multicolumn{2}{c|}{ Total } & \\
\cline { 2 - 6 } & Amount & $\mathbf{\%}$ & Amount & \% & Amount & \% & \\
\hline Clean Behavior and Healthy Lifesyle & \\
\hline Adequate & 2 & 40,0 & 3 & 60,0 & 5 & 100,0 & \\
\hline Poor & 27 & 93,1 & 2 & 6,9 & 29 & 100,0 & \\
\end{tabular}

Based on the results of statistical tests using the chi square test analysis at the $95 \%$ confidence level, it shows that there is a statistically significant relationship between the level of clean and healthy living behavior and the incidence of scabies in respondents with a value of $p=0.015$ ( $p$ value $\leq 0.05$ )

This research is in line with research conducted by Ridho Zakarsi which states that respondents with positive scabies have very poor hygiene and healthy living habits with the highest number, amounted 20 respondents (25.0\%) with a value of $\mathrm{p}=0.002$, so there is a significant relationship between behavior of respondents to the incidence of scabies [26].

In the literature, it is stated that one of the causes of scabies is unhealthy behavior. Scabies transmission can occur through direct and indirect contact [2]. This statement is also supported by research conducted by Muafida et al., namely the respondents' habit of borrowing tools and toiletries from each other, respondents rarely clean the bed, and through direct contact includes skin-to-skin contact, for example shaking hands and sleeping together with people with scabies [27]. At the Al Baaqiyaatushsholihaat Islamic Boarding School students still often lend goods to each other and during the day the students 'mattresses which are used for sleeping at night are folded and supported into one with the other students' mattresses. This will lead to the spread of scabies directly.

\section{CONCLUSION}

Based on the result, there was statistically significant relationship between knowledge and incidence of scabies among students at the Al Baaqiyaatushsholihaat Islamic Boarding School $(\mathrm{p}=0.007)$. In addition, there was also statistically significant relationship between clean behavior and healthy lifestyle and the incidence of scabies among students at the Al Baaqiyaatushsholihaat Islamic Boarding School $(\mathrm{p}=0.015)$.

\section{REFERENCES}

[1] M. Mading dan I. Sopi, "Kajian aspek epideiologi scabies pada manusia," Kemenkes RI, vol. 2, pp. 9-18, 2015.

[2] S.A. Boediardja dan R.P. Handoko, "Skabies: Ilmu penyakit kulit dan kelamin," 7th ed. In S.L. Menaldi, K. Bramono, W. Indriatmi, Editors. Jakarta: FKUI Publishing Agency, 2015, pp. 137-140.

[3] Desmawati, A.P. Dewi, dan O. Hasanah, "Hubungan personal hygiene dan sanitasi lingkungan dengan kejadian skabies di Pondok Pesantren Al-Kautsar Pekanbaru," Jurnal Online Mahasiswa Universitas Riau, vol. 2, pp. 28-37, 2015.

[4] T.B. Fitzpatrick, "Fitzpatrick's Dermatology In General Medicine," 7th Ed. In K. Wolff, A. Goldsmith Lowell, I. Katz Stephen, A. Gilchrest Barbara, S. Paller Amy, J. Leffell David, Editors. Newyork: McGraw Hill Medical, 2008, pp. 2029-2032.

[5] I. Ma'rufi, E. Istiaji, dan E. Witcahyo, "Hubungan perilaku sehat santri dengan kejadian scabies di pondok pesantren Kabupaten Lamongan,' IKESMA, vol. 8, no. (2). pp. 119-129, 2012. 
[6] R. Majid, R.D.I. Astuti, dan S. Fitriyana, "Hubungan Personal Hygiene dengan Kejadian Skabies pada Santri di Pesantren Kabupaten Bandung," Jurnal Integrasi Kesehatan dan Sains, vol. 2, no. (2), pp. 160-164, 2020.

[7] S. Sungkar, Skabies: etiologi, patogenesis, pengobatan, pemberantasan, dan pencegahan. Jakarta: Badan Penerbit Fakultas Kedokteran Universitas Indonesia, 2016, pp. 86-88.

[8] D. Murtiastutik, E. Ervianti, I. Agusni, dan S. Suyoso, Editors. Atlas penyakit kulit dan kelamin, 2nd Ed. Surabaya: Airlangga University Press, 2009, pp. 61-64.

[9] H. Ibadurrahmi, S. Veronica, dan N. Nugrohowati, "Faktor-faktor yang berpengaruh terhadap kejadian penyakit skabies pada santri di Pondok Pesantren Qotrun Nada Cipayung Depok Februari tahun 2016," Jurnal Profesi Medika: Jurnal Kedokteran dan Kesehatan, vol. 10, no. (1). pp. 33-45, 2017.

[10] S. Puspita, E. Rustanti, dan M.K. Wardani, "Hubungan Personal Hygiene Dengan Kejadian Skabies Pada Santri,” Jurnal Keperawatan, vol. 11, no. (2), pp. 33-8, 2018.

[11] Darmopoli, Pesantren modern IMMIM pencetak muslim modern. Jakarta: Rajawali Pers, 2011, p. 116

[12] S. Prayogi dan B. Kurniawan, "Pengaruh personal hygiene dalam pencegahan penyakit skabies," Jurnal Majority, vol. 5, no. (5), pp. 140 $143,2016$.

[13] Kementrian Kesehatan RI, Pedoman pembinaan perilaku hidup bersih dan sehat (PHBS). Jakarta: Kemenkes RI, 2011.

[14] C. Tresnasari, T. Respati, M. Maulida, Y. Triyani, M. Tejasari, Y Kharisma, and I. Ismawati, "Understanding scabies in religious boarding school (pesantren)," In Social and Humaniora Research Symposium (SoRes 2018), vol. 307, pp. 520-522, 2019. Paris: Atlantis Press.

[15] Pangkalan Data Pondok Pesantren (PDPP), "Statistik data pondok pesantren," 2019. [Online]. Retrieved from: https://Ditpdpontren.Kemenag.Go.Id/Pdpp/Statistik [Accessed on: March 20th, 2021].

[16] N.P. Sari dan S. Mursyida, “Analisis Personal Higiene dan Pengetahuan dengan Kejadian Skabies pada Santri di Pondok Pesantren Al-Ikhwan Kota Pekanbaru tahun 2017," Jurnal Kesehatan Komunitas, vol. 4, no. (2), pp. 63-67, 2018

[17] Wijaya dan Y.P. Mandala, "Faktor-faktor yang berhubungan dengan kejadian scabies pada santri di Pondok Pesantren Al Makmur Tingkar,
Kabupaten 50 Kota Tahun 2011," Jurnal Kesehatan Holistik, vol. 11, pp. $1-4,2011$.

[18] Kementrian Agama Jawa Barat, "Data pondok pesantren berdasarkan tipe 2018," 2019. [Online]. Retrieved from: https://Jabar.Kemenag.Go.Id/Artikel-43396-Data-Pondok-PesantrenBerdasarkan-Tipe-2018 [Accessed on: March 20 $0^{\text {th }}, 2021$ ].

[19] Z. Naftassa dan T.R. Putri, "Hubungan Jenis Kelamin, Tingkat Pendidikan Dan Pengetahuan Terhadap Kejadian Skabies Pada Santri Pondok Pesantren Qotrun Nada Kota Depok," Biomedika, vol. 10, no. (2), pp. 115-119, 2018.

[20] S.R.T. Handari, "Analisis Faktor Kejadian Penyakit Skabies di Pondok Pesantren An-Nur Ciseeng Bogor 2017," Jurnal Kedokteran dan Kesehatan, vol. 14, no. (2), pp. 74-82, 2018.

[21] A. Avidah, E. Krisnarto, dan K. Ratnaningrum, "Faktor Risiko Skabie di Pondok Pesantren Konvensional dan Modern," Herb-Medicine Journal, vol. 2, no. (2), pp. 58-63, 2019.

[22] A.R. Ridwan, S. Sahrudin, dan K. Ibrahim, "Hubungan pengetahuan, personal hygiene, dan kepadatan hunian dengan gejala penyakit skabies pada santri di Pondok Pesantren Darul Muklisin Kota Kendari 2017,' (Jurnal Ilmiah Mahasiswa Kesehatan Masyarakat), vol. 2, no. (6), pp. 1$8,2017$.

[23] S. Notoatmojo, Kesehatan masyarakat ilmu dan seni. Jakarta: Rineka Cipta, 2007

[24] R.N. Rohmawati, "Hubungan antara faktor pengetahuan dan perilaku dengan kejadian skabies di Pondok Pesantren Al-Muayyad Surakarta,' Biomedika, vol. 15, pp. 1-14, 2010.

[25] U.D. Hilma dan L. Ghazali, "Faktor-faktor yang mempengaruhi kejadian skabies di pondok pesantren mlangi nogotirto gamping sleman yogyakarta," Jurnal Kedokteran Dan Kesehatan Indonesia, vol. 6, no. (3), pp. 148-157, 2014.

[26] R. Zakarsi, Hubungan perilaku hidup bersih sehat dan tingka pendidikan dengan kejadian skabies di Pesantren Nurul Ummah Kotagede Yogyakarta. Electronic Theses and Dissertasions, Surakarta: Universitas Muhammadiyah Surakarta, 2019.

[27] N. Muafida, I. Santoso, and D. Darmiah, "The Relation of Personal Hygiene with The Incidence of Scabies at Al Falah Male Boarding School Students Sub-district of Liang Anggang in the Year 2016," Journal of Health Science and Prevention, vol. 1, no. (1), pp. 1-9, 2017. 